E International

\title{
Tourism Facilitation as part of Transport Policy
}

Summary of International Experiences

A joint ITF-OECD Study

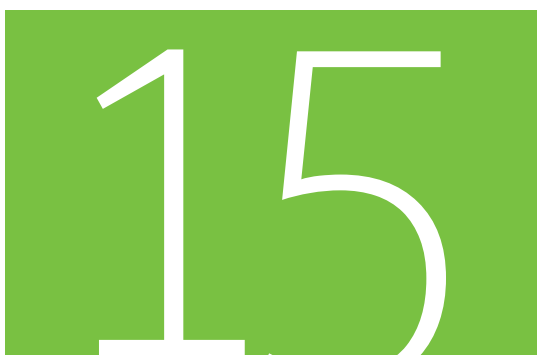

Discussion Paper 2015 • 15 


\section{Tourism Facilitation as part of Transport Policy \\ Summary of International Experiences}

Discussion Paper No. 2015-15

May 2015 


\section{THE INTERNATIONAL TRANSPORT FORUM}

The International Transport Forum at the OECD is an intergovernmental organisation with 54 member countries. It acts as a strategic think-tank, with the objective of helping shape the transport policy agenda on a global level and ensuring that it contributes to economic growth, environmental protection, social inclusion and the preservation of human life and well-being. The International Transport Forum organises an Annual Summit of ministers along with leading representatives from industry, civil society and academia.

The International Transport Forum was created under a Declaration issued by the Council of Ministers of the ECMT (European Conference of Ministers of Transport) at its Ministerial Session in May 2006 under the legal authority of the Protocol of the ECMT, signed in Brussels on 17 October 1953, and legal instruments of the OECD.

The Members of the Forum are: Albania, Armenia, Australia, Austria, Azerbaijan, Belarus, Belgium, Bosnia and Herzegovina, Bulgaria, Canada, Chile, China (People’s Republic of), Croatia, Czech Republic, Denmark, Estonia, Finland, France, Former Yugoslav Republic of Macedonia, Georgia, Germany, Greece, Hungary, Iceland, India, Ireland, Italy, Japan, Korea, Latvia, Liechtenstein, Lithuania, Luxembourg, Malta, Mexico, Republic of Moldova, Montenegro, Netherlands, New Zealand, Norway, Poland, Portugal, Romania, Russian Federation, Serbia, Slovak Republic, Slovenia, Spain, Sweden, Switzerland, Turkey, Ukraine, United Kingdom and United States.

The International Transport Forum's Research Centre gathers statistics and conducts co-operative research programmes addressing all modes of transport. Its findings are widely disseminated and support policymaking in member countries as well as contributing to the Annual Summit.

\section{Discussion Papers}

The International Transport Forum’s Discussion Paper Series makes economic research, commissioned or carried out at its Research Centre, available to researchers and practitioners. The aim is to contribute to the understanding of the transport sector and to provide inputs to transport policy design.

ITF Discussion Papers should not be reported as representing the official views of the ITF or of its member countries. The opinions expressed and arguments employed are those of the authors.

Discussion Papers describe preliminary results or research in progress by the author(s) and are published to stimulate discussion on a broad range of issues on which the ITF works. Comments on Discussion Papers are welcomed, and may be sent to: International Transport Forum/OECD, 2 rue AndréPascal, 75775 Paris Cedex 16, France.

For further information on the Discussion Papers and other JTRC activities, please email: itf.contact@oecd.org

The Discussion Papers can be downloaded from www.internationaltransportforum.org/jtrc/DiscussionPapers/jtrcpapers.html

The International Transport Forum's website is at: www.internationaltransportforum.org

This document and any map included herein are without prejudice to the status of or sovereignty over any territory, to the delimitation of international frontiers and boundaries and to the name of any territory, city or area. 


\section{Table of contents}

INTRODUCTION

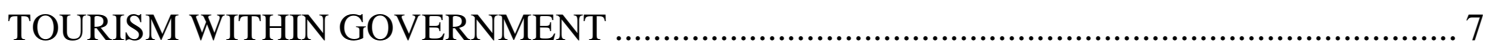

MINISTRY OF TRANSPORT STRATEGIC PLANNING AND TOURISM FACILITATION11

COLLABORATION BETWEEN THE MINISTRY OF TRANSPORT AND OTHER DEPARTMENTS IN FORMULATING TOURISM POLICY ….................................................. 13

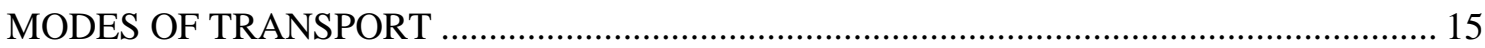

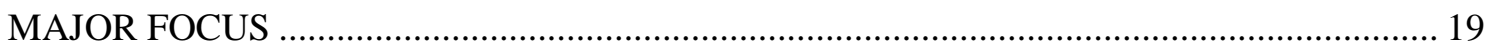

TOURISM-RELATED TRANSPORT DATA SOURCES AND DATA GAP …...................... 21

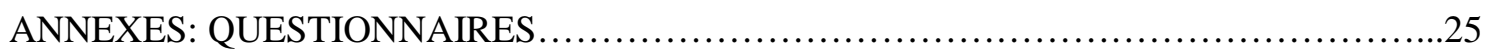




\section{Introduction}

With over one billion international tourist arrivals per year, forecast to rise to 1.5 billion per year by 2020, transport is an essential component of the tourism system. Transport connects tourism generating regions (both domestic and international) to destinations, and facilitates the internal movement of visitors between attractions, accommodation, and commercial services. The location, capacity, efficiency and connectivity of transport can therefore play a significant role in how a destination develops, significantly influencing the mobility of visitors and the connectivity of tourist experiences within destinations. At the same time the growing number of travellers creates numerous challenges in terms of transport infrastructure and capacity, border crossing, intermodality, information for travellers and inter-operability of technologies with tourism service providers.

In preparation for the International Transport Summit 2015: Transport, Trade and Tourism, a survey was carried out to understand whether tourism facilitation is regularly incorporated into Ministries of Transport's overall transport strategic planning and if the Ministry systematically collaborates with stakeholders in tourism policy development. 29 member countries of the International Transport Forum participated in the survey. The questionnaire is attached as an annex to this paper.

A similar survey was undertaken concurrently by colleagues within the OECD Tourism Unit, to better understand the inclusion of transport policy, and collaboration with the transport industry, in the development of tourism policy. Responses were received from 20 OECD and 2 Partner countries. This questionnaire is also attached to this paper. 


\section{Tourism within government}

Tourism is a big business worldwide. It is a key service export for many economies around the world and contributes to job creation and economic development at the national, regional and local levels. In OECD member countries, tourism directly contributes, on average, around 5\% of GDP, 6\% of employment, and $21 \%$ of exports of services. When considering the total impact of tourism, including direct, indirect and induced impacts, tourism represents around 9\% of GDP and employment (OECD 2014).

Table 1. Top-10 international tourist arrivals

\begin{tabular}{l|r|r} 
& $\mathbf{2 0 1 3}$ & $\mathbf{1 3 / 1 2} \%$ \\
\cline { 2 - 3 } 1 France & 84.7 & $2.0 \%$ \\
2 United States & 69.8 & $4.7 \%$ \\
3 Spain & 60.7 & $5.6 \%$ \\
4 China & 55.7 & $-3.5 \%$ \\
5 Italy & 47.7 & $2.9 \%$ \\
6 Turkey & 37.8 & $5.9 \%$ \\
7 Germany & 31.5 & $3.7 \%$ \\
8 United Kingdom & 31.2 & $6.4 \%$ \\
9 Russia & 28.4 & $10.2 \%$ \\
10 Thailand & 26.5 & $18.8 \%$ \\
\hline
\end{tabular}

Source: UNWTO.

Recognising the importance of tourism, there is a department or unit responsible for tourism policy in all participating countries. Among these countries, only Bulgaria, Croatia, Israel and Mexico have a separate, independent Ministry for Tourism. In other countries, tourism is one of the competencies within a Ministry with multiple portfolios. For example, in Serbia: the Ministry of Trade, Tourism and Telecommunications; and in the United Kingdom: the Department for Culture, Media and Sports.

The potential synergies between transport and tourism policy are clear, and governments have an important role to play in addressing the inter-linkages between these policy areas. For example:

- $\quad$ Transport policy (e.g. airport/cruise hubs, roads, public transport) can shape access to and travel patterns within destinations, influencing visitor accessibility, mobility and satisfaction;

- $\quad$ Transport policy can facilitate a shift to more eco-friendly transport options, enabling destinations to position themselves as sustainable; 
- $\quad$ Tourism policies can stimulate movement to and within a destination, which can in turn emphasise seasonal peaks and troughs, push transport capacity limits, and place pressure on existing infrastructure capacity;

- Conversely, tourism policies can help to secure the economic viability of local transport systems.

Participating countries also acknowledge the importance of the transport sector in supporting and facilitating tourism growth. Despite these synergies, only three countries assign transport and tourism to the same Ministry:

- $\quad$ Ireland: Department of Transport, Tourism and Sport

- Japan: Ministry of Land, Infrastructure, Transport and Tourism

- $\quad$ Slovakia: Ministry of Transport, Construction and Regional Development

In Belgium, since the installation of the new Flemish Government in July 2014, mobility and tourism became the competencies of the same Minister, to better streamline tourism mobility issues. In Wallonia, mobility and tourism remains the responsibility of different ministries.

Some countries separate the responsibility for tourism strategic planning from policy execution:

- $\quad$ In New Zealand, the Ministry of Business, Innovation and Employment undertakes research and provides policy advice on matters related to tourism. The marketing of New Zealand as an international tourist destination falls under the responsibility of Tourism New Zealand, a crown entity funded by the government.

- In Flemish Belgium, tourism policy falls under the domain of Foreign Affairs within the Government of Flanders, whereas the promotion of Flanders is carried out by an autonomous organisation called Visit Flanders.

- In Switzerland, the national tourism policy falls within the State Secretariat for Economic Affairs while the marketing is carried out by Suisse Tourisme, a public enterprise. 
Table 2. Transport and tourism in selected governments

\begin{tabular}{|c|c|c|}
\hline \multirow{2}{*}{ Country } & \multicolumn{2}{|c|}{ Ministries responsible for } \\
\hline & TOURISM & TRANSPORTATION \\
\hline Australia & Department of Foreign Affairs and Trade & $\begin{array}{l}\text { Department of Infrastructure and Regional } \\
\text { Development }\end{array}$ \\
\hline Austria & $\begin{array}{l}\text { Ministry of Science, Research and } \\
\text { Economy }\end{array}$ & $\begin{array}{l}\text { Ministry of Transport, Innovation and } \\
\text { Technology }\end{array}$ \\
\hline Belgium(W) & Ministry of Local Authorities and Cities & \\
\hline Canada & Industry Canada & \\
\hline Chile & $\begin{array}{l}\text { Ministry of Economy, Development and } \\
\text { Tourism }\end{array}$ & Ministry of Transport \\
\hline Czech Rep. & Ministry of Regional Development & Ministry of Transport \\
\hline Denmark & Ministry of Business and Growth & Ministry of Transport \\
\hline Finland & $\begin{array}{l}\text { Ministry of Employment and the } \\
\text { Economy }\end{array}$ & Ministry of Transport and Communication \\
\hline France & $\begin{array}{l}\text { Ministère de l'Économie, des Finances et } \\
\text { de l'Industrie }\end{array}$ & \\
\hline Greece & $\begin{array}{l}\text { Ministry of Economy, Infrastructure, } \\
\text { Shipping and Tourism }\end{array}$ & $\begin{array}{l}\text { Ministry of Infrastructure, Transport and } \\
\text { Networks }\end{array}$ \\
\hline Israel & Ministry of Tourism & Ministry of Transportation \\
\hline Italy & Ministry of Cultural Heritage and Tourism & \\
\hline Mexico & Ministry of Tourism & Ministry of Communications and Transport \\
\hline New Zealand & $\begin{array}{l}\text { Ministry of Business Innovation and } \\
\text { Employment }\end{array}$ & \\
\hline Poland & Ministry of Sport and Tourism & \\
\hline Portugal & Minist & of Economy \\
\hline Slovak Rep. & Ministry of Transport, Const & uction and Regional Development \\
\hline Slovenia & $\begin{array}{l}\text { Ministry of Economic Development and } \\
\text { Technology }\end{array}$ & \\
\hline Spain & Ministry of Industry, Energy and Tourism & \\
\hline Sweden & Ministry of Ent & prise and Innovation \\
\hline Turkey & Ministry of Culture and Tourism & $\begin{array}{l}\text { Ministry of Transport, Maritime Affairs and } \\
\text { Communications }\end{array}$ \\
\hline Croatia & Ministry of Tourism & $\begin{array}{l}\text { Ministry of Maritime Affairs, Transport and } \\
\text { Infrastructure }\end{array}$ \\
\hline Egypt & Ministry of Tourism & Ministry of Transport \\
\hline
\end{tabular}




\section{Ministry of Transport strategic planning and tourism facilitation}

Recognising the inextricable links between transport and tourism, responses from the survey suggest that most participating countries do consider tourism facilitation in the Ministry's overall transport strategic policy, though often it is not the priority objective. In addition, whether tourism facilitation is systematically included in transport strategic policy and the level of importance, differ widely among countries.

In Iceland: "tourism is a core element of the national transport plan, both long and short term and it is incorporated in the legislative requirements of the transport strategic policy plan."

In Latvia: "Transport facilitation is not defined as a separate transport policy objective. However, the Transport Development Guidelines 2014-2020 notes that transport development contributes positively in the development of tourism in the country."

In Russia, tourism facilitation is usually not part of the Ministry of Transport's strategic planning, except for issues related to mass transportation and tourist mobility during major events, for example, the Universiade 2013, Sochi Winter Olympic Games and the upcoming FIFA World Cup in 2018.

Emerging countries in the Balkan region tend to focus on actual infrastructure modernisation as their main priorities, given existing dilapidated transport system. Bulgaria and Bosnia-Herzegovinian acknowledge better transport infrastructure will significantly improve accessibility and contribute to regional tourism development. Both countries cooperate and receive funding from the European Union and other international financing institution including the European Investment Bank and the European Bank for Reconstruction and Development on infrastructure upgrade projects.

Results from the survey also suggest that tourism facilitation is more often included in Ministry of Transport medium to long-term strategic policy. Short-term planning is more likely to be administered at the local level to better attend to immediate local priorities.

From a tourism policy perspective, the great majority of responding countries acknowledged the clear inter-linkages with transport, which are reflected in a range of tourism-related policies incorporating elements on aviation, land transport (in particular rail and bicycle), and sea/cruise infrastructure. Ten countries indicated that transport was a key consideration in the development of Tourism Strategies (Australia, Austria, Canada, Chile, Czech Republic, Egypt, New Zealand, Slovenia, Spain, and Turkey). Specific examples of air transport policies taken into consideration include open skies agreements (Israel and Egypt), attracting and developing new air routes/connections/aviation linkages (Denmark, Portugal and New Zealand), and stable employment in airport facilities (Spain).

In efforts to boost bicycle tourism, Austria has developed criteria for measuring the quality of bicycle-routes. Denmark has published a national bicycle strategy which has led to the discussion of how to develop Denmark into an even better holiday destination for bicycle tourists. France is seeking 
to develop bicycle touring and has established an inter-ministerial group on the use of bicycles. Slovak Republic has considered the National Strategy of Development of Cycling Transport and Cycle tourism in drawing up Tourism Development up to 2020. 


\section{Collaboration between the Ministry of Transport and other departments in formulating tourism policy}

Most countries participating in the survey confirmed there is some collaboration between the Ministry of Transport and other departments in formulating tourism policy. Nevertheless, the level and scope of cooperation and the frequency of exchanges differ widely among member countries.

In Japan: "The Ministerial Council for the promotion of Japan as a tourism oriented country was established in 2013. The council consists of the entire cabinet presided by the Prime Minister, meaning the Ministry of Land, Infrastructure, Transport and Tourism develops policy by involving all ministries."

In Austria, Tourism falls under the competence of the Federal Ministry of Science, Research and Economy. The Ministry collaborates closely with the Federal Ministry for Transport, Innovation and Technology and the Federal Ministry of Agriculture, Forestry, Environment and Water Management at the national level. All three federal ministries also collaborate with regional authorities, municipalities, tourism boards and other industrial stakeholders.

Similarly, vertical cooperation is also in place in Switzerland, while in Ireland public consultation also feeds into tourism policy development.

Some countries reported that their Ministries of Transport are not involved in tourism policy development but provide opinions, recommendations and answers to queries from departments. For example, Transport Canada has consulted the Canadian Tourism Commission for tourism related policies but does not typically develop tourism policy. A similar arrangement is also cited by Croatia and Latvia.

On the contrary, there is limited contact between the Ministry of Transport and the ministry responsible for tourism in Denmark and New Zealand.

\section{Box. Special planning and collaboration for peak tourist season in Croatia}

As a part of preparation for each tourist season, the Ministry of Tourism convenes an annual meeting with participants from various departments (including Transport) where all key areas are covered with designated coordinators which act according to necessity. In keeping with that, cooperation between the Ministry of Tourism and the Ministry of Maritime Affairs, Transport and Infrastructure is efficient and very operational. 
From a tourism policy perspective, the great majority of responding countries again indicated that ministries responsible for tourism collaborated with Transport and other ministries (e.g. Austria with the Ministry of Agriculture, Forestry, Environment and Management; Denmark with the Ministry of Environment and Ministry of Health; and New Zealand, with the Department of Conservation) in developing transport policy. Australia, Chile, Finland, Israel, Mexico, Spain, and Egypt all mentioned the importance of collaboration between agencies in air transport.

In Australia, the Tourism Access Working Group (TAWG) was established as one of nine initial working groups to implement Australia's National Long-Term Tourism Strategy, launched in December 2009. TAWG ensures the needs of the tourism industry are considered by Government during transport and infrastructure planning.

Greece, Spain and Egypt mentioned rail transportation as an area where the Ministry in charge of tourism has collaborated. Other areas of collaboration in participating countries include signage (Mexico and Egypt), cycling (Denmark), and GHG emissions (Austria).

In relation to collaboration with transport industry associations, all but three countries indicated that industry views were sought in the development of tourism-related policy. Four countries (Australia, Canada, Mexico, and Spain) have established specific mechanisms for cooperation with industry, while more than half seek industry views in preparing tourism strategies or implementing activities such as promotion. 


\section{Modes of transport}

Results from the survey show that a Ministry of Transport may collaborate with other departments regarding tourism facilitation on selected modes of transport only. For example, in Serbia, the Ministry of Construction, Transport and Infrastructure collaborate with other departments in formulating tourism policy pertaining to rail, air and waterborne transport but not in the road sector.

Figure 1. Global inbound tourism by mode of transport

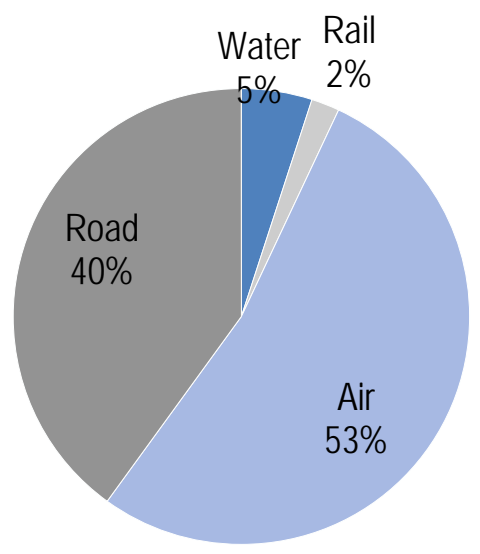

Source: UNWTO Tourism Highlights 2014.

\section{Air sector}

Countries recognise the importance of air connectivity as a major trade and tourism facilitator. According to United Nations World Tourism Organization, 53\% of inbound tourists arrive by air. Survey results suggest there is usually some collaboration between the transport ministry and tourism department in formulating strategic transport policy in the air sector. For example, Spain identifies tourism as an essential economic contributor and incorporates tourism in its air sector transport strategic policy: Plan de Desarrollo del Sector Aéreo; and Transport Canada considers key markets identified by the Canadian Tourism Commission in formulating the Blue Sky policy.

\section{Rail sector}

Rail is a mean of transport that can be an attraction in itself. In Turkey, the Ministry of Transport, Maritime Affairs and Communications collaborates with the Ministry of Culture and Tourism in developing tourism policy on the rail sector. Examples of this collaboration include the restoration and 
preservation of historical buildings along railway lines and the organisation of special train grouptours to Eastern Anatolia, Eastern Black Sea and regions within the South-Eastern Anatolia project (GAP) area.

In Flanders, the government has plans to modernise the coastal tram line to improve mobility and promote tourism. Cross-country collaboration projects on rail tourism include the "Visit Alps by train" project and the Baltic Adriatic Transport Axis Cooperation, where the role of rail will be improved for passenger, tourism and freight purposes

\section{Road sector}

Road infrastructure is often considered the backbone for mobility. Nevertheless, it is an area where there is limited information on the incorporation of tourism facilitation in countries strategic road transport policies. Survey responses suggest that the most common collaboration between tourism and the road sector relate to accessibility to tourist zones; and better organisation and visibility of road signage relates to tourism sites.

In Austria, the Federal Ministry for Transport actively promotes electric mobility for sustainable tourism development. Many tourist destinations offer visitors electric powered cars and two-wheelers to rent. In Switzerland, local traffic congestion and parking are major issues in some Alpine tourist zones. Various authorities coordinate to promote the usage of public transport and monitor private vehicle traffic.

\section{Waterborne sector}

Waterborne activities include open sea, coastal and inland waterways cruises, sailing, and other water related recreational activities. In most participating countries, waterborne passenger transport is usually identified as a special tourism-aimed infrastructure area. In the Czech Republic, measures to develop the waterborne sector are included in the Transport Policy document. Similarly, Poland's Transport Development Strategy 2020 contains plans on "improving the navigability and modernisation of infrastructure on recreational waterways”. In Turkey, functions within the Ministry of Transport organise regular exchanges with stakeholders and sectorial institutions to ensure adequate coastal structures and port facilities for tourism purposes. 
Figure 2. Domestic Tourists Mode-Share, 2013

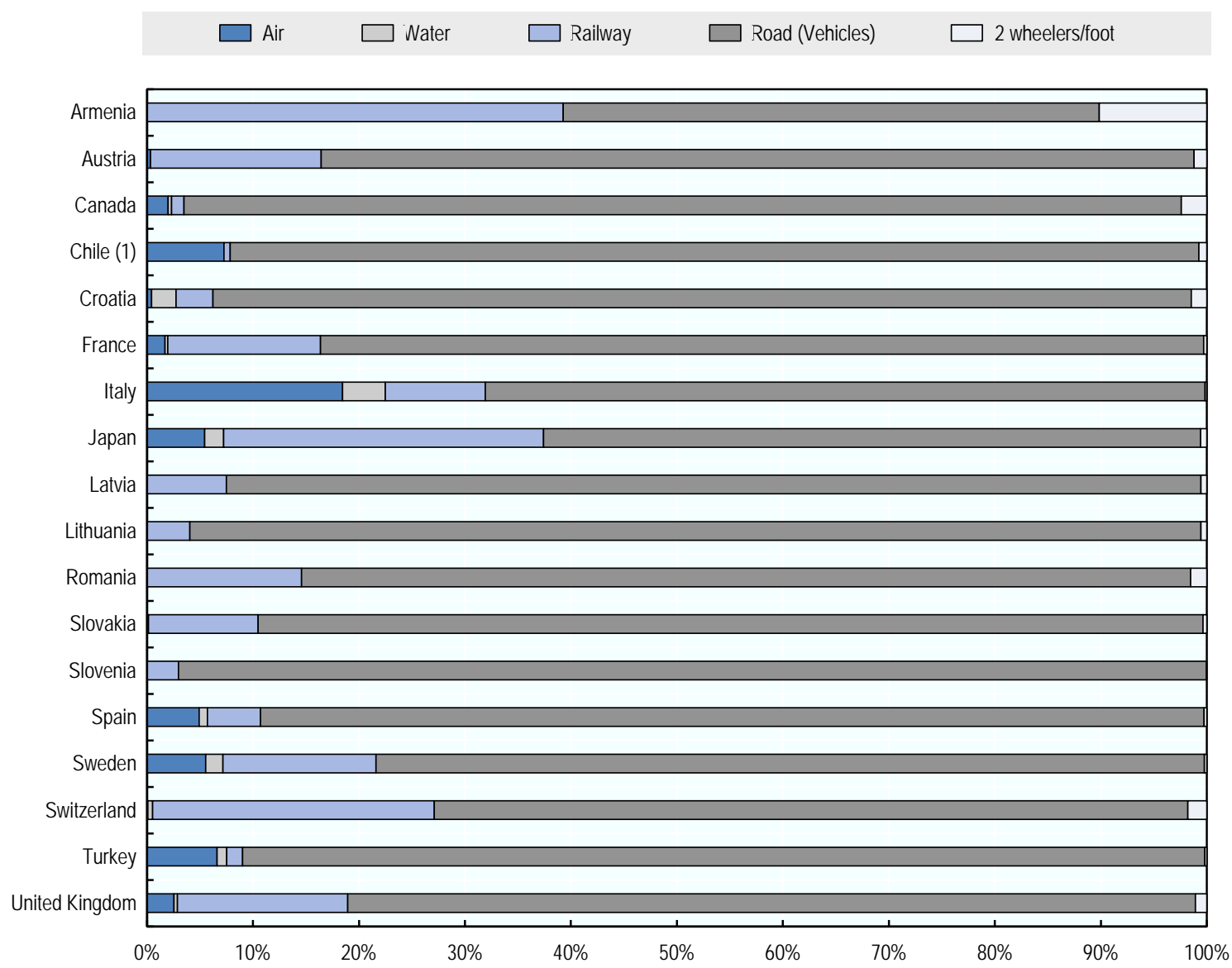

Note: (1) 2012 data. Source: UNWTO Compendium of Tourism Statistics 2015 Edition

\begin{abstract}
Box. New Zealand: Geographical location
The role of the transport system in supporting tourism is most obvious in the aviation sector. Air services are vital to New Zealand's economy, with almost all tourists arriving by air. The Ministry of Transport has primary responsibility for the conduct of international air services negotiations. The number of tourists which New Zealand can attract is affected by the availability of scheduled air service agreements.

Each new air link or shipping service has significant flow-on effects throughout the economy. Strong international transport links facilitate tourism, help businesses to be better connected, and better positioned to seize the opportunities that arise from the flow of people, ideas, capital and trade across borders.

For many shipping lines and airlines, New Zealand is already a marginal proposition. To entice airlines and shipping companies to operate in the New Zealand market, New Zealand needs to ensure that their policy and regulatory settings continue to promote growth and innovation. As such our focus is on promoting an open, effective and competitive market. This is done by providing information, avoiding unnecessary compliance costs, and where possible, looking for new opportunities to reduce costs and improve regulatory efficiency while maintaining safety and environmental standards.
\end{abstract}


Table 2. Inbound and domestic tourism by mode of transport, 2013

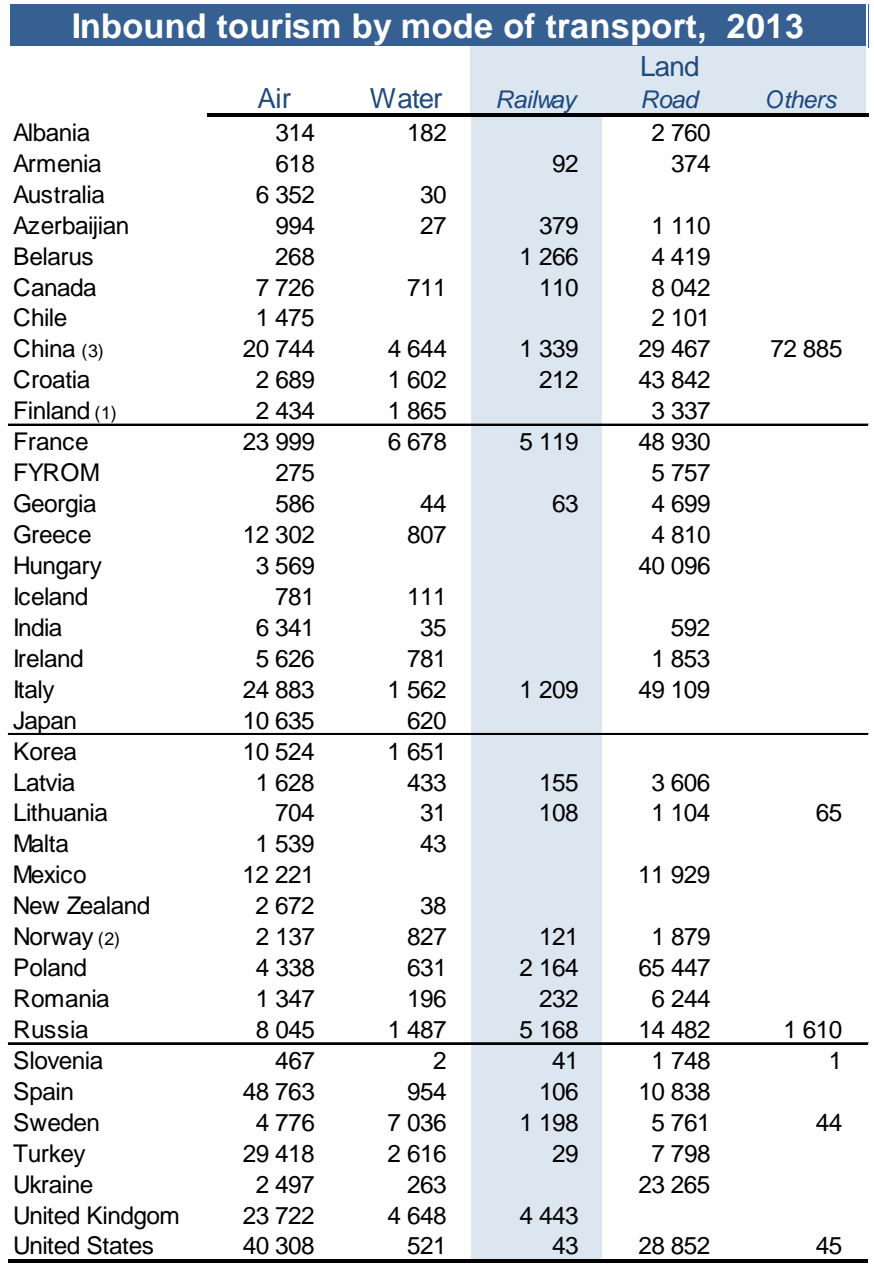

\begin{tabular}{|c|c|c|c|c|c|}
\hline \multicolumn{6}{|c|}{ Domestic tourism by mode of transport, 2013} \\
\hline Armenia & & & 263 & 339 & 68 \\
\hline Austria & 39 & 2 & 1889 & 9657 & 143 \\
\hline Canada & 6357 & 1074 & 3785 & 301269 & 7783 \\
\hline Chile $_{(1)}$ & 1489 & & 119 & 18740 & 158 \\
\hline Croatia & 70 & 365 & 554 & 14620 & 234 \\
\hline France & 3062 & 493 & 26037 & 150448 & 556 \\
\hline Italy & 11660 & 2550 & 5945 & 42890 & 109 \\
\hline Japan & 53989 & 17904 & 299442 & 615433 & 6095 \\
\hline Latvia & & & 237 & 2901 & 18 \\
\hline Lithuania & & & 105 & 2469 & 15 \\
\hline Romania & & & 2384 & 13722 & 251 \\
\hline Slovakia & 7 & & 493 & 4248 & 18 \\
\hline Slovenia & & & 60 & 1964 & 1 \\
\hline Spain & 7130 & 1101 & 7256 & 128647 & 392 \\
\hline Sweden & 2712 & 791 & 7075 & 38225 & 123 \\
\hline Switzerland & 61 & 283 & 17503 & 46823 & 1197 \\
\hline Turkey & 4524 & 624 & 1021 & 62150 & 133 \\
\hline United Kingdom & 2880 & 350 & 18090 & 89970 & 1210 \\
\hline
\end{tabular}

Note: (1) 2012 data; (2) 2011 data; (3) Including ethnic Chinese arriving from Hong Kong, Macau, Chinese Taipei and overseas Chinese, of which most same-day visitors are from Hong Kong and Macao. Source:

UNWTO Compendium of Tourism Statistics 2015 Edition. 


\section{Major focus}

Countries have different government priorities, geography, economic and social development. This leads to a diverse range of foci in incorporating tourism into strategic transport policy formulations. Nonetheless, several broad focus themes may be drawn from the responses:

- $\quad$ Safety

Safe, resilient and efficient transportation system for locals and tourists alike is a permanent political and social goal for all countries. In Luxembourg, motorcycle tourism safety is taken on-board in the Ministry's transport policy planning due to recurrence accidents. In Serbia, the transport ministry cooperates with stakeholders to formulate safety requirements for recreational water-based crafts. In Canada, Transport Canada supports domestic tourism, which is the focus of provincial ministries, through ensuring safe and efficient movement of people on the national level.

\section{- $\quad$ Signage}

Signage improvement and standardisation have been evoked by several countries. For example, Visit Flanders organised meetings to improve signage related to tourism on highways and cities and to create attractive and recognisable tourist information point at important transport hubs. In France, the "Improve the quality of hospitality" working group which included the Ministry responsible for transport and other public and private actors, made recommendations on harmonisation of signage system in railway station, airports and metro stations in Paris and on the creation of tourist information portals in multiple languages.

\section{- $\quad$ Cycling-tourism}

Cycling is increasingly popular for its environmental and health benefits. Countries not only promote cycling as a sustainable and accessible mode of transport, but also increasingly tap into the potential of cycling tourism. In Ireland, the Department of Transport, Tourism and Sport provided funding for the construction of the 'scenic greenways' cycling path, which runs along an old railway line, over viaducts and through mountainous tunnels overlooking the Atlantic Ocean in western Ireland. In Slovakia, the Ministry of Transport, Construction and Regional Development includes cycling tourism development strategy in their National Cycling-Transport and Cycle-Touring Strategy report.

\section{- $\quad$ Technology and cross border sustainable development}

New technology is increasingly used to make the current transportation systems 'smarter'. The cross-border mobility information network system is made available to inform users of the most seamless and sustainable travelling options. For example, the AlpInfoNet project aims to provide locals and tourists with comprehensive information on sustainable multi-modal transport beyond national borders. The broad objective is to increase the use of public transport in the Alpine region, 
and therefore to reduce the local environmental impact. The project involves 13 partners from 5 countries in the Alpine region, including the Austrian, French and German Ministries of Transport. Other examples of cross-border multimodal cooperation on sustainable transport mobility and tourism development include the “Trans-Danube” and “Access 2 Mountain” project. 


\section{Tourism-related transport data sources and data gap}

Tourism related transport data are collected by different surveys from various sources on national, regional and local level. Major data sources include transport data, household survey, immigration records or border survey and visitor survey.

Despite these multiple data sources, data gap remains. The major challenge for transport policy makers in tourism facilitation planning is the lack of data on actual tourist movement (origindestination) and mobility behaviour (modes of transport) on the national level: where exactly do they go during their visits and how do they reach those destinations?

Transport data captures the total number of passengers transported without knowing travel purpose. For example, Swiss Federal Railways cannot distinguish commuters from tourists travelling by RER train between Geneva and Lausanne in its data reporting. Depending on modes and countries, actual true origin-destination is not always available in transport data either, for example in the Paris metro system and some local trains in France. Air transport and high speed rail are the two exceptions where true origin-destination data are readily available; but only when passengers do not switch to other modes of transport.

\section{Figure 3. Tourism in transport data}

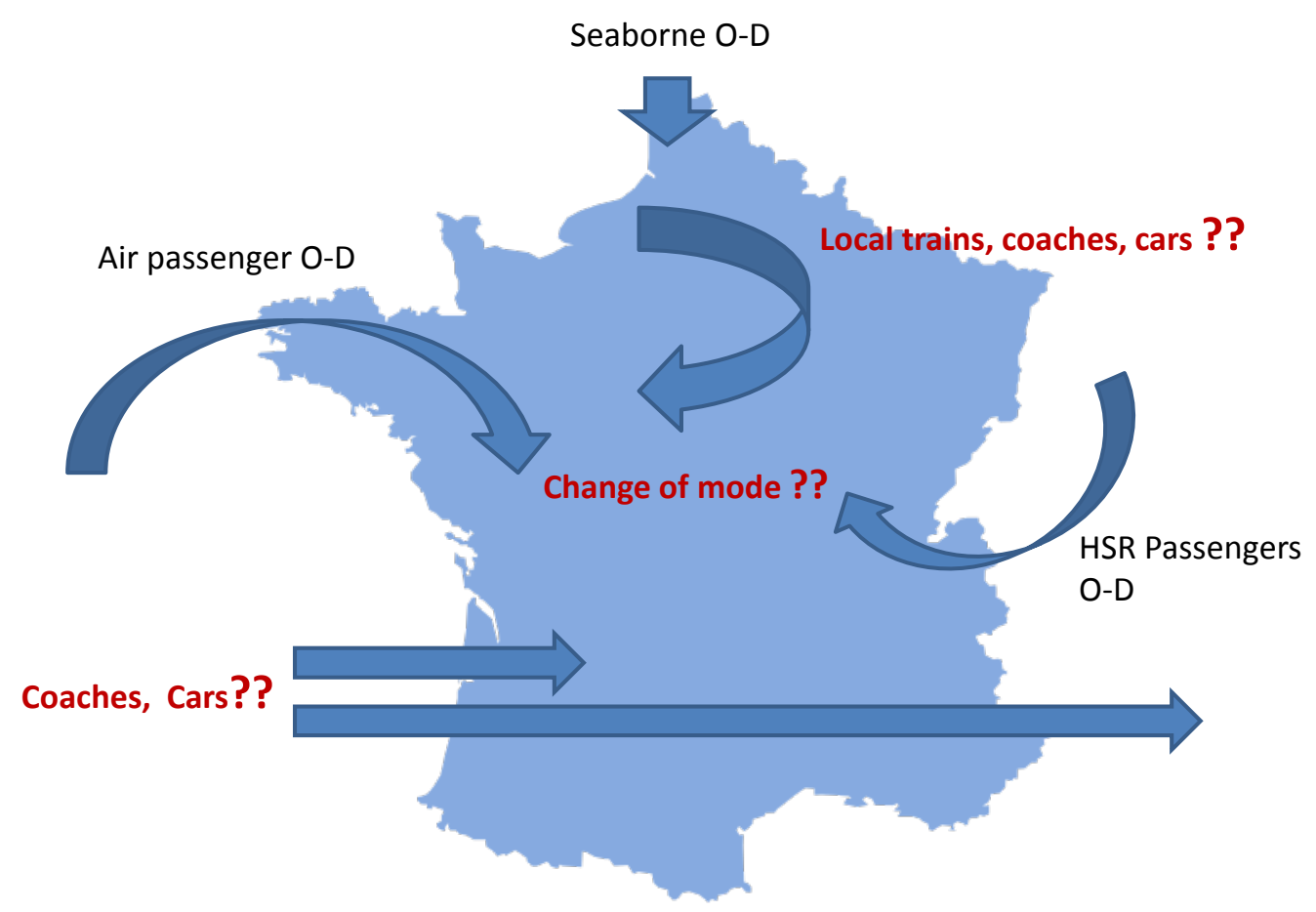


Household survey provides information on trip purpose and modes of transport. It includes data on average distance for leisure trips travelled but not origin-destination. The survey is seldom carried out (usually once every 5-10 years) and does not include non-residents, meaning foreign tourists are excluded.

Immigration records or border survey contains the number of inbound tourists, countries of origin and modes of transport on arrival at the borders. However, the data does not capture their onwards travel plans: the "where do they go next and how" part. Within the Schengen area, data accuracy is further complicated by the freedom of movement for residents and tourists alike.

Visitor survey is usually carried out on the regional and local level, or for a specific venue and event. Each survey is designed to best fit its objective. The survey may contain partial origindestination and modal share data. It provides useful information for local planning but may not necessarily add up to policy planning on the national level.

Figure 4. Tourism in other data sources

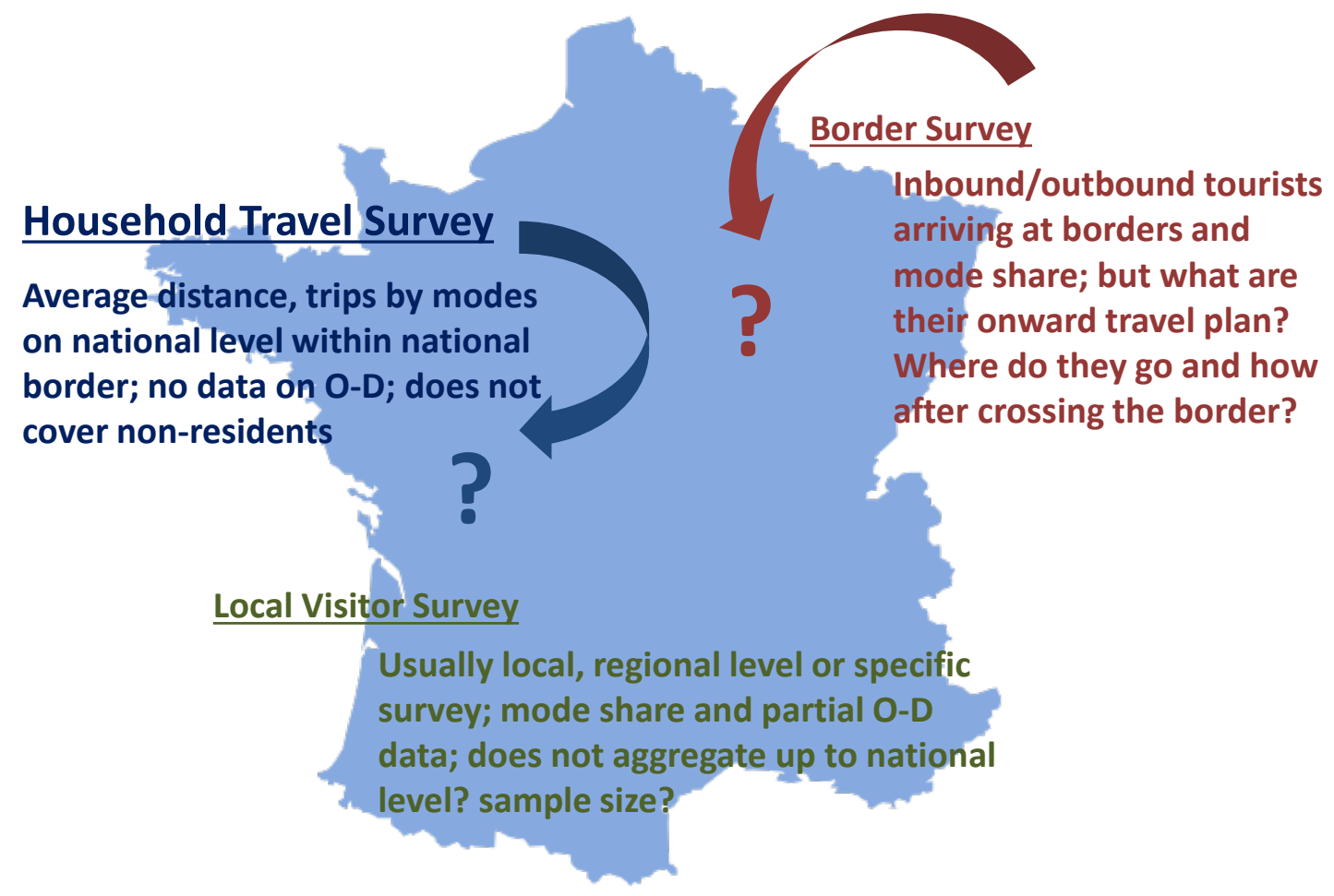

In addition, diverse methodologies and definitions used among different surveys may make crosscomparison analysis difficult.

The lack of actual origin-destination data is echoed by countries as this impacts efficient policy planning:

- $\quad$ The Iceland Government noted that it would be of interest to have more comprehensive data on tourists travel plans for better preparation of seasonal service needs. 
- $\quad$ In New Zealand, the Ministry of Transport does not have good measure of kilometres driven by foreign license holders. This makes it difficult to measure the riskiness of foreign drivers of different nationalities compared to New Zealand drivers over time.

- $\quad$ Latvia suggests that mobile position data which can capture detailed information on tourism flows would be useful for the development of transport infrastructure and onsite tourism facilities.

Tourism ministries indicated that of the data collected for improving the development and assessment of tourism/transport related policies, much of it focusses on the number of passengers by mode of transport, with a data collection usually undertaken by the national statistical office or the Ministry responsible for tourism or National Tourism Organisation. 
Table 3. Data sources for transport and tourism

\begin{tabular}{|c|c|c|c|}
\hline & Organisation & Tourism Data & Transport Data \\
\hline Australia & $\begin{array}{l}\text { Tourism Research Australia } \\
\text { Bureau of Infrastructure, Transport and Regional } \\
\text { Economics }\end{array}$ & Visitor survey & aviation statistics data \\
\hline Austria & $\begin{array}{l}\text { Statistics Austria } \\
\text { ANTO }\end{array}$ & $\begin{array}{l}\text { Accommodation, Travel habits, Travel balance of } \\
\text { payments, Satellite systems } \\
\text { T-MONA: data on tourists including the type of } \\
\text { transportation }\end{array}$ & \\
\hline Chile & $\begin{array}{l}\text { External institutions } \\
\text { Civil Aviation Board } \\
\text { Ministry of Public Works } \\
\text { Directemar } \\
\text { Sernature }\end{array}$ & Surveys at the national airport & $\begin{array}{l}\text { passengers on domestic flights } \\
\text { registration of car flow throw of concession tolls } \\
\text { cruise passengers }\end{array}$ \\
\hline Czech R. & $\begin{array}{l}\text { Ministry for regional development and Czech } \\
\text { Statistical Office }\end{array}$ & Tourism statistics & Data on air, railway, road, waterborne transport \\
\hline Denmark & $\begin{array}{l}\text { Ministry of Transport } \\
\text { Danish Statistics Bank }\end{array}$ & & $\begin{array}{l}\text { Data on bicycle tourists } \\
\text { Various statistics (passenger traffic on } \\
\text { ferries/bridges), airport statistics }\end{array}$ \\
\hline Finland & $\begin{array}{l}\text { Finnish Transport Agency } \\
\text { Ministry of Transport \& Communications + } \\
\text { Finnish Transport Agency } \\
\text { Statistics Finland } \\
\text { Finnish Transport Agency } \\
\text { FINAVIA }\end{array}$ & & $\begin{array}{l}\text { National Travel Survey } \\
\text { Fintrip (Finnish Transport Research and } \\
\text { Innovation Partnership) } \\
\text { Transport statistics (Accommodation statistics, } \\
\text { Border Interview Survey, Canal traffic, Domestic } \\
\text { waterborne traffic and etc.) } \\
\text { Traffic statistics (Road statistics, shipping } \\
\text { statistics, railway statistics) } \\
\text { Aviation Statistics }\end{array}$ \\
\hline Greece & $\begin{array}{l}\text { Ministry of Tourism do not collect data } \\
\text { Hellenic Statistical Authority }\end{array}$ & Annual international arrivals and occupancy rates & \\
\hline Israel & Ministry of Tourism & Inbound tourism survey & \\
\hline Italy & Working Group & & $\begin{array}{l}\text { The collection of data on regional and local } \\
\text { mobility is ongoing. }\end{array}$ \\
\hline Mexico & $\begin{array}{l}\text { Ministry of Tourism (Statistical Compendium of } \\
\text { Tourism) including information on transport }\end{array}$ & & 7 point (air, road and maritime flow) \\
\hline New Zealand & Ministry of Business, Innovation and Employment & $\begin{array}{l}\text { Do not collect a lot of data for this purpose, but } \\
\text { feed contextual information into the process of } \\
\text { e.g. visitor arrivals statistics, tourism flow data, } \\
\text { visitor expenditure data and tourism trends. }\end{array}$ & \\
\hline Portugal & & & $\begin{array}{l}\text { The route performance statistics which the } \\
\text { airports produce }\end{array}$ \\
\hline Slovak R. & Published on the website of the MoT & Tourism statistics & $\begin{array}{l}\text { Useful: Data on air, railway, road as well as } \\
\text { waterborne transport }\end{array}$ \\
\hline Spain & $\begin{array}{l}\text { Turespana - FROTUR statistics provided by } \\
\text { Aena } \\
\text { Renfe } \\
\text { Puertos del Estado } \\
\text { General Directorate of Traffic } \\
\text { Tourespana }\end{array}$ & $\begin{array}{l}\text { Quantifying the number of foreign visitors } \\
\text { Connectivity relations } \\
\text { Tourism expenditure Survey }\end{array}$ & $\begin{array}{l}\text { Flights and international passengers } \\
\text { Passengers on international flights } \\
\text { Passenger data arriving at ports } \\
\text { Road traffic entrance and exits }\end{array}$ \\
\hline Sweden & $\begin{array}{l}\text { National level } \\
\text { The Swedish Agency for Economic and Regional } \\
\text { Growth }\end{array}$ & $\begin{array}{l}\text { Passengers on different modes of transportation } \\
\text { Accommodation, tourism economic impacts, } \\
\text { border survey, etc. }\end{array}$ & \\
\hline Turkey & $\begin{array}{l}\text { Ministry of Transport, Maritime Affairs and } \\
\text { Communications collected and evaluated the data } \\
\text { used to develop transportation and infrastructure } \\
\text { strategy. }\end{array}$ & & \\
\hline Croatia & $\begin{array}{l}\text { Central Bureau for Statistics } \\
\text { Publication by NTO }\end{array}$ & $\begin{array}{l}\text { Data on the way of transport our tourists use } \\
\text { Border crossing by type of vehicle }\end{array}$ & \\
\hline Egypt & & $\begin{array}{l}\text { Number of passengers/tourists by mode of } \\
\text { transport and by destination }\end{array}$ & $\begin{array}{l}\text { Number of transport users, cars, tourism } \\
\text { vehicles, number of accidents per year and by } \\
\text { geographical distribution }\end{array}$ \\
\hline
\end{tabular}


Annex 1. ITF Transport and Tourism Survey

\section{Questionnaire for: Tourism in Transport Policy}

\section{COUNTRY:}

Notes:

$>$ Please complete the Questionnaire by inserting your text under each section title.

$>$ For each section, please provide information/comments on all modes of transport (i.e. air, sea, rail, road, inland waterways)if applicable/possible. You may add in charts, tables, graphs, pictures etc.to better illustrate your text.

> Please complete this Questionnaire and return to us by deadline : 09-January-2015.

> If you have any questions, comments or concerns, please contact: edouard.chong@oecd.org

1. Under which ministry is "tourism” organized?

Example: Ministry of Land, Infrastructure, Transport and Tourism (Japan); Ministry of Tourism (Greece) ...

2. Is tourism facilitation being incorporated into the Ministry of Transport's overall long, medium or short-term transport strategic policy?

If yes, please elaborate by providing policy examples or links to document access.

3. Does the Ministry of Transport collaborate with other departments in developing tourism policy?

If yes, please elaborate by providing policy examples or links to document access.

4. What data are collected for improving assessment of tourism/transport related policies? Are there any additional data which may be useful? 
Annex 2. OECD Tourism Survey

\section{Questionnaire for: Transport in Tourism Policy}

\section{COUNTRY:}

\section{Notes:}

$>$ Please complete the Questionnaire by inserting your text under each section title.

$>$ Please provide information/comments by mode of transport (i.e. air, sea, rail, road, inland waterways) if applicable/possible. You may add in charts, tables, graphs, pictures etc. to better illustrate your text. You may also provide supporting documentation (including links).

$>$ Please complete this Questionnaire and return to us by deadline : 16-January-2015.

$>$ Please do not hesitate to contact the Secretariat should you need further information: peter.haxton@oecd.org or jane.stacey@oecd.org

5. Is transport policy being incorporated into the Ministry's overall long, medium or short-term strategic tourism policy?

If yes, please elaborate by providing examples of the type (formal or informal, regular or ad hoc etc.) and outcomes of policy collaborations, including links to supporting documents.

6. Does the Ministry in charge of tourism collaborate with other departments in developing transport policy?

If yes, please elaborate by providing policy examples and links to supporting documents.

7. Does the Ministry in charge of tourism collaborate with transport industry representatives in developing strategic tourism policy or specific programmes for travelers?

If yes, please elaborate by providing examples of the type and outcomes of collaborations (e.g. policy, promotion, information for tourists), including links to supporting documents.

8. What data are collected for improving the development and assessment of tourism/transport related policies? Are there any additional data which may be useful? 